\title{
Students' Perception of Daylight Illumination in the School Workshop as a Determinant for Effective Students' Task Performance in Workshop Practice
}

\author{
Japo Oweikeye Morto Amasuomo ${ }^{1} \&$ Abigail Ngozi Alio ${ }^{2}$ \\ ${ }^{1}$ Department of Vocational/Industrial Education, Niger Delta University, Yenagoa, Bayelsa State, Nigeria \\ ${ }^{2}$ Department of Technology and Vocational Education, Enugu State University of Science and Technology, \\ Agbani, Enugu State, Nigeria \\ Correspondences: Japo Oweikeye Morto Amasuomo, Department of Vocational/Industrial Education, Niger \\ Delta University, Wilberforce Island, P. O. Box 1033 Yenagoa, Bayelsa State, Nigeria. E-mail: \\ japoamasuomo@gmail.com
}

Received: September 29, $2013 \quad$ Accepted: November 4, $2013 \quad$ Online Published: November 18, 2013

doi:10.5539/jel.v2n4p201

URL: http://dx.doi.org/10.5539/jel.v2n4p201

\begin{abstract}
The study investigated daylight illumination in the school workshop as a determinant for effective students' task performance in workshop practice. 183 NCE Technical students in 300 Level which comprised of 73 and 112 students from Federal Colleges of Education (Technical), Asaba and Omoku, Nigeria respectively during the 2008/2009 academic session was used for the study The daylight Illumination Task Performance Questionnaire (DITPQ) was used to collect data. The students perceived that there was inadequate daylight illumination of the school workshop and it negatively affected effective students' task performance workshop practice; and no significant difference existed in the students' mean perception scores of daylight illumination in the school workshop as a determinant for their effective task performance in workshop practice.
\end{abstract}

Keywords: daylight, illumination, determinant, workshop, performance

\section{Introduction}

The need for students to acquire adequate and effective workshop practice has generated a lot of concern among technology and vocational teachers and this concern also affects the Nigerian Certificate in Education (NCE) Technical programme. The NCE Technical programme is a three year course of study offered in the Colleges of Education in Nigeria with a philosophy aimed at providing technical teachers with intellectual and professional background adequate for teaching technical subjects and to make them adaptable to any changing situation in technological development not only in the country but in the world at large (National Commission Colleges for Education (NCCE), 2008). The philosophy of the NCE (Technical) programme has not been able to achieve its aim of accelerating scientific and technological development because, lack of foresight on the part of policy makers in terms of providing the enabling environment for true technological advancement. Thus, a lot of research works have been carried out over the years on the problems affecting effective workshop practice in technology and workshop education.

In addition, students in technology and vocational training can only acquire manipulative skills when they are exposed to effective workshop practice instead of only theoretical teaching. Students exposed to effective practical training shall be to utilize the knowledge acquired in the school workshop in their future employment in industries or factories that manufacture products are related to their areas of specialization while at school. In essence, the practical training received by students in the school workshops should compare relatively with that of the industry where the trainee will subsequently work (Elobuike, 1998; and Duru, 2001).

However, most research works on the lack of effective workshop practice are centre around the teachers instructional especially when the conventional lecture method (Etukudo, 2004; and Wodi, 2005); inadequate workshop spaces, equipment/tools and training materials (Duru, 2001; and Enamali, 2006) and the qualification and competence of the teacher (Georgewill, 1996). Further, it has been observed that in some colleges, the students have being engaged in relative practical work and some of the teachers also competent and qualified, yet the students still record poor performance in practical work. This suggest that other factors apart from 
availability of equipment/ tools, training materials, workshop and laboratory spaces, and adequate supply of qualified lecturers are responsible for lack of effective students' task performance in workshop practice.

From the foregoing, this study therefore considered daylight illumination of the school workshop space as a determinant for effective students' task performance in workshop practice. The sun is the natural source of daylight illumination. Light promotes seeing and it is used in performing visual tasks such as reading or operating equipment. When it is used for critical visual tasks, a sufficient amount of illumination is required for the task than when it is used for ambient lighting (Prouse, 2003; and Evans, 2008). The Illumination Engineering Society as cited by Sanders and McCormick (1993) defined light as radiant energy that is capable of exciting the retinal (of the eye) and producing a visual sensation. Bridger (2003) also defined light as that portion of electromagnetic spectrum which can be detected by the human visual system. Anyakoha (2006) further defined light as a form of energy called luminous energy, which causes a sensation of vision that enables us see.

Daylighting is therefore, the controlled admission of natural light into a space through the windows to reduce or eliminate electric lighting (Ander, 2006). Heschong (2002) also defined daylighting as the practice of using natural light from the sun or sky to produce illumination in interior environment. Daylight produces the best illumination for work (Blum and Naylor, 2004) and provides direct link to the dynamic and perpetually evolving pattern of outdoor illumination and creates a visually stimulating and productive environment for building occupant (Ander, 2006). Good daylight illumination of building space therefore depends on the type, area and dimension of window openings; the distribution and location of lights; the intensity of light and well distributed luminance free from glare (Greene, 1997).

Daylight illumination in any interior space to large extent determines the utilitarian as well as the aesthetic environment. The functions of daylight illumination according to (Callender, 1997) therefore are the illumination of interior room spaces; illuminate the tasks, and illuminate for safety. Kalstrom (1999) further stated that, to maximize the natural light, bring it into the building at as high an elevation as possible. Daylight illumination enlivens space and increases user satisfaction and visual comfort leading to improved performance. Heschong (2002) also observed that, daylight makes a difference, not only in helping buildings become energy efficient, but also for students who learn more effectively. Daylight illumination has long been the standard measure of lighting quality because it gives off continuous spectrum of all light wavelengths including blue, red and green appearing as a bright white.

Daylighting should illuminate a task appropriately and to an appropriate extent so that the visual mechanism can function at high level of efficiently (Jones, 2002). The functioning of visual mechanism at higher level of efficiency is a requirement when there are some tasks to be carried out, such as assembling or repairing of instruments; operating mechanical equipment etc (Vandenberg, 1979). Good lighting ensures safety, reduces work hazards, facilitates productivity or performance of task, and creates an appropriate visual environment to enhance a better working condition for personnel and employee morale (Wentz, 1999).

Our sense of sight is very important in and out of the work place. Accidents can therefore be caused by failure to see or failure to understand what is seen. Most accidents that are caused by poor illumination are avoidable with proper planning in the use of daylight illumination. Improper planning for day lighting introduces glare and shadows; reduced vision and increases visual fatigue, which may lead to accidents (Wentz, 1999). Therefore, the various factors should be considered in providing adequate daylight illumination for interior room spaces are visual needs of the task; time duration of the works; visual capabilities of the personnel; potential visual hazards; probability of errors, and consequences of the error (Wentz, 1999).

Daylight illumination brings about stresses when daylighting is not properly and adequately harnessed. Indicators of stress from daylight illumination are visual distress, physical and mental fatigue. Circumstances for which daylight illumination can cause visual distress are glare, veiling reflection and flickering light source. Inadequate daylighting causes glare when there is excessive or unwanted brightness that is present in the visual field of view of an observer. However, glare is a subjective experience Therefore, the extent to which a person experience a glary condition is fundamentally dependent upon how each person's visual system operates. However, conditions that cause discomfort will not necessarily reduce visual acuity or the ability to see but these conditions will produce a situation where an occupant's visual performance will suffer (Heerwagen, 2004). Further, Winterbottom and Wilkins (2009) reported that, aspects of classroom lighting and decor that can promote discomfort can impair task performance through glare. It means that, when the occupant is forced to experience conditions of visual distress for some time; the individual's vision will progressively degrade as fatigue and discomfort increase. 
Veiling reflection also causes visual distress when light enters an observer's field of view and reflects on the task surface or when the luminance of light is substantially brighter than the generalized light that is illuminating the task surface. The veiling reflection generally establishes a non-uniform distribution across the task surface (Heerwagen. 2004). Thus, a surface of veiling reflection produces localized lighting that interferes on the general lighting condition of a task. Further, flickering light causes visual distress due to poor daylighting. Flickering according to Heerwagen (2004) is a sensation that one experiences when a light source cycles on and off rapidly. This cycling of light source produces an intermittent stimulation of retinal photoreceptor cells and creates visual discomfort. Thus, flickering can be created by electric light source, such as fluorescent, lamps when it has developed some fault. It can also be caused through the action of wind when tree branches are in the pathway of light coming into a room space.

Daylight illumination apart from causing visual distress can also cause physical and mental fatigue when one performs visual tasks in settings where there is insufficient support for good vision or unevenly lighted room space (Blum, and Naylor, 2004; and Heerwagen, 2004). Such conditions include not having adequate luminance on a task surface or enough contrast between the detailed item and its background. Visual fatigue can happen in an environment that are in most respects supportive, but which have some conditions that places a strain on the visual system or eye (discomfort) which causes physical pains in the eye muscles and mental fatigue which results in headaches (Blum and Naylor, 2004; and Basu, Sahu and Datta. 2006). A person who experiences such eye strain for a lengthy period of time becomes more prone to accidents.

Daylight illumination in any work environment depending on its adequacy and appropriateness may cause visual distress, physical and mental fatigue or improves the seeing environment and this it in turn determines the performance of individuals in a given task. Good lighting increases accuracy of colour judgement, ensures safety, facilitates the performance of tasks and creates an appropriate visual environment by making details easier to see and colours easier to discriminate without producing discomfort or distraction or introducing additional hazards to the work place (Wentz 1999: and Bell Greene, Fisher and Baum, 2006). However, performance itself is a combination of visual, cognitive and motor components (Sanders and McCormick, 1993) because lighting itself cannot produce work output but influences the performance of tasks by improving the visual aspects of a task.

Inadequate daylighting aggravates visual fatigue because support for good vision is inadequate. Visual fatigue leads to task performance decrement. Performance decrement due to impaired visual acuity may lead to low productivity, reduced accuracy, quality and uniformity of products; and increases accidents in work place and low mechanism for improved task performance. Conversely, adequate daylight illumination enlivens space, enhances user satisfaction, and accurate task performance; and increases productivity, improves the quality and uniformity of products, reduces errors and accidents, and provides smooth and soothing work environment as well as nurturing a careful and responsible work attitude (Wentz, 1999; Ander, 2006; and Basu, Sahu and Datta, 2006).

To improve work productivity and health, Kalstrom (1999) reported that, the two most significant improvements you can make to the work place are natural lighting and indoor air quality. Heschong (2002) observed that, the amount of daylight in the classroom was found to be strongly associated with better student performance. Fielding (2002) also observed that, while planning learning environments, teachers frequently request that we want plenty of windows and full spectrum lighting and not those cold fluorescents. He further reported that, there has been a demonstrative correlation between daylighting and academic performance. In conclusion, adequate and good daylight illumination creates mechanism for improved performance since workers can use the increased ease of seeing to increase output if they have the motivation and ability to do so.

From the available literature, it has been established that, daylight illumination in the work environment is a determinant for an individuals' effective task performance. This suggests further study on whether daylight illumination in the school workshop will also be a determinant for effective students' task performance in workshop practice. The purpose of the study is specifically aimed at finding out the students' perception of daylight illumination as a determinant for effective students' task performance in workshop practice in the two the Federal Colleges of Education (Technical), at Asaba and Omoku in South-South Nigeria

The following research questions derived from the purpose of the study was formulated as guide: To what extent will students from Federal Colleges of Education (Technical), at Asaba and Omoku respectively perceive daylight illumination as a determinate for effective students' task performance in workshop practice? Based on the research question, a null hypothesis to be tested at 0.05 level of significance is as follows: There is no significant difference on the extent to which students from Asaba and Omoku respectively will perceive daylight illumination as a determinant for effective students' task performance in workshop practice. 


\section{Research Method}

The study adopted a descriptive survey research design. The area of the study was the two Federal Colleges of Education (Technical) in South-South, Nigeria located at Asaba, Delta State and Omoku, Rivers State. The population for the study was 185, and it comprised 73 and 112 NCE Technical Education students from Asaba and Omoku who were in 300 Level. Data were obtained from the Schools of Technical Education during the 2008/2009 academic. The NCE Technical Education programme is a three training that leads to the award of Nigeria Certificate in Education (NCE). The 300 Level students were chosen for the study because they offer the entire courses listed in the first and second years of the NCE programme before choosing an area of specialization in third year (NCCE, 1990). The colleges were funded by the Federal Government of Nigeria with common workshops used for workshop practice. The final year students are expected to have reasonable knowledge of workshop practice.

The instrument for data collection was the Daylight Illumination and Performance Questionnaire (DIPQ) to collect data on the responses of students on the extent to which they perceived daylight illumination in the school workshop as a determinant for effective task performance in workshop practice. The DIPQ had four items in form of statements and the response options were Very great extent (VGE), Great extent (GE), Moderate extent (ME), Low extent (LE), and Very low extent (VLE) on a 5-point scale.

The DIPQ instrument was face-validated by professional colleagues at the Federal College of Education (Technical), Omoku to ensure that, the items in the questionnaire were in line with research questions and the hypotheses that will be tested. The reliability test of the instrument used thirty 300 Level NCE Technical Education students from Federal College of Education (Technical), Umunze, Anambra State, Nigeria during the 2008/2009 academic session who were not part of the study. The college was used because it runs the same NCE Technical Education programme. The result of the Cronbach Alpha Coefficient test of reliability for the DIPQ instrument was 0.74 , indicating the reliability instrument.

The DIPQ questionnaire for Omoku was administered by the researcher and that of Asaba was administered by a trained research assistant. Retrieval of questionnaire was 70 copies from the students at Asaba out of the 73 copies administered, representing 95.89 percent; and 97 copies from students at Omoku out of 112 copies administered, and representing 86.60 percent.

The Arithmetic mean and standard deviation was used to establish the extent to which students perceived daylight illumination as a determinant for effective students' task performance in workshop practice. And on a 5-point scale, the decision rules assigned to the students' responses thus: Very great extent, (4.50-5.000); Great extent, (3.50-4.49); Moderate extent, (2.50-3.49); Low extent, (1.50-2.49); and Very low extent, (1.00-1.49). The null hypothesis was tested with Z-test of independent group means at 0.05 level of significance for two tailed to establish whether there was no significant difference in the responses among students from Federal College of Education (Technical), Asaba and Omoku respectively on the extent to which they perceived daylight illumination as a determinant for effective task performance in workshop practice.

\section{Data Analysis}

The results of Research Question on the extent to which students from the two colleges at Asaba and Omoku respectively perceived daylight illumination as a determinate for effective students' task performance in workshop practice presented in Table 1 used daylight illumination determinant indicators as visual distress (low visual acuity), visual fatigue (straining of eyes), mental fatigue (restlessness), and low visual impression. 
Table 1. Students' perception scores on daylight illumination as a determinant for effective task performance in workshop practice

\begin{tabular}{|c|c|c|c|c|c|}
\hline \multirow[t]{2}{*}{ Noise stress indicators } & \multicolumn{2}{|c|}{ Asaba } & \multicolumn{2}{|c|}{ Omoku } & \multirow[b]{2}{*}{ Decision } \\
\hline & $\mathrm{X}_{\mathrm{A}}$ & $\mathrm{SD}_{\mathrm{A}}$ & $\mathrm{X}_{0}$ & $\mathrm{SD}_{0}$ & \\
\hline $\begin{array}{l}\text { 1. Daylight illumination which reduces visual } \\
\text { distress (low visual acuity) is a determinant } \\
\text { for smooth visual work environment leading } \\
\text { to less workshop accidents. }\end{array}$ & 4.03 & 1.15 & 4.07 & 1.13 & Great extent \\
\hline $\begin{array}{l}\text { 2. Daylight illumination which reduces visual } \\
\text { fatigue (straining of eyes) is a determinant for } \\
\text { accuracy of colour judgment, quality and } \\
\text { uniformity in task performance. }\end{array}$ & 3.88 & 1.13 & 4.14 & 0.85 & Great extent \\
\hline $\begin{array}{l}3 \text { Daylight illumination which reduces mental } \\
\text { fatigue (restlessness) is a determinant for } \\
\text { quantity and uniformity of task. }\end{array}$ & 3.76 & 1.15 & 3.88 & 1.01 & Great extent \\
\hline $\begin{array}{l}\text { 4. Daylight illumination improves low visual } \\
\text { impression is a determinant for colour } \\
\text { perception ability. }\end{array}$ & 3.90 & 0.99 & 4.05 & 1.02 & Great extent \\
\hline Grand mean $\left(\mathrm{X}_{\mathrm{G}}\right)$ & 3.89 & 1.11 & 4.04 & 1.00 & Great extent \\
\hline
\end{tabular}

The students' Grand Perception Mean ( $\left.\mathbf{x}_{\mathbf{G}}\right)$ scores of 3.89 and 4.04 for from Asaba and Omoku respectively revealed that, daylight illumination was a determinant for students' effective task performance in workshop practice to a great extent. The Grand Mean Standard Deviations $\left(\mathbf{x}_{\mathbf{G}}\right)$ of 1.11 to 1.00 for the students' perception response scores from Asaba and Omoku were small; not widely dispersed but clustered and close to the mean indicating a small variability and therefore homogeneous.

The results of the hypothesis presented in Table 2 indicated that there was no significant difference in the mean scores of students from Federal College of Education (Technical), Asaba and students from Federal College of Education (Technical), Omoku on the extent of their perception of daylight illumination as a determinant effective task performance in workshop practice.

Table 2. Z-test for students' perception scores of daylight illumination as a determinant for effective task performance in workshop practice

\begin{tabular}{lllllllll}
\hline Colleges & $\mathrm{N}$ & $\mathrm{X}$ & $\mathrm{SD}$ & $\mathrm{Df}$ & $\mathrm{P} \leq$ & Z-calculated & Z-critical & Decision \\
\hline Asaba & 70 & 3.89 & 1.11 & 165 & 0.05 & 0.90 & 1.65 & Not significant \\
Omoku & 97 & 4.04 & 1.00 & & & & & Ho: not rejected \\
\hline
\end{tabular}

From the results, the Z-calculated of 0.90 was less than the Z-critical of 1.65 . Therefore, the null hypothesis was not rejected at $\mathrm{P} \leq 0.05$.

\section{Discussion}

The result of the research question established that daylight illumination in a school workshop was a determinant for students' effective task performance in workshop practice. That is, it was the perception of the students from the two colleges that, adequate daylight illumination in the workshop space which reduced visual distress (low visual acuity), visual fatigue (straining of eyes), and menial fatigue (restlessness) was a determinant task performance in colour perception ability and smooth visual work environment, accuracy of colour judgement, quality and uniformity, and visual control and pattern recognition in task performance to a great extent. In this regard Boyce (2003) established that, inadequate illumination of work space decreases work output and visual acuity; and that appropriate daylight illumination makes colours easier to discriminate and details easier to see, and workers can use this increase ease of seeing to increase work output. Wentz (1999); and Ander (2006) also reported that, it is inadequate daylighting that aggravates visual fatigue because support for good vision is 
inadequate. And that, visual fatigue leads to task performance decrement in terms of low productivity; reduced accuracy; and increased accidents in workplace; and low visual mechanism for improved task performance. In addition, Basu, Sahu and Datta (2006) opined that, inappropriate illumination of any room space will affect the visual effectiveness of an individual in terms of distraction, annoyance and visual fatigue. Pattron (2009) further reported that, output and accuracy of an individual's task performance in a work environment increases with increase in illumination output. The implication of the finding was that daylight illumination was a determinant for effective task performance; and inappropriate and inadequate daylight illuminations adversely affected uniformity, quantity and accuracy of jobs.

When the null hypothesis was tested at 0.05 significance level, no significant difference existed on the extent to which students from Federal Colleges of Education (Technical) at Asaba and Omoku respectively perceived daylight illumination school workshop as a determinant for effective task performance in workshop practice. It was therefore, the opinion of the students from both Colleges that daylight illumination that reduces visual distress (low visual acuity), visual fatigue (eye straining) and mental fatigue (restlessness) was a determinant for effective task performance in workshop practice. in this regard, Chao, Lijun and Xiangpei (2011) opined that, brightness if the key factor of environment and the quality of it can influence task performance, comfort and well being. In addition, it was the views of Musa, Abdullah, Che-Ani, Tawil and Tahir (2012) that, lighting plays a very important part in our life, and it is one of the parameters that influence indoor environment quality. From the foregoing, daylight illumination of a workshop space that is appropriate enough to enhance task performance is very vital the school workshop.

\section{Conclusion/Recommendation}

From the findings of the study, it was the perception of the students that daylight illumination in the school workshop was a determinant for effective task performance in workshop practice. Further, the students' mean perception scores from the Federal College of Education (Technical), Asaba and their counterparts from Omoku did not differ significantly on the extent to which daylight illumination was a determinant for effective task performance in workshop practice. Thus, daylight illumination was a determinant for effective students' task performance in workshop practice at the Federal Colleges of Education South-South, Nigeria.

Based on the findings of the study and to mitigate the negative effects of daylighting on students' effective task performance in workshop practice, it was recommended that, the workshop spaces should have adequate and appropriate daylight illumination through proper and adequate placement of side windows and roof lightning (clerestory). However, general lighting should be uniform, widely distributed to avoid harsh shadows of strong contrasts, and be subdued to avoid direct or reflective glare.

\section{References}

Ander, G. D. (2006). Day lighting. Retrieved May 25, 2006, from http// wbdg. Org/design/day lighting. Php

Anyakoha, M. W. (2006). New school physics low senior secondary schools. Onitsha, Nigeria: Africana First Publishers Ltd.

Basu, S. K., Sahu, K. C., \& Datta, N. K (2006). Works organization and management. Delhi: Oxford and IBH Publishing Co. Pvt Ltd.

Bell, P. A., Greene, T. C., Fisher, J. D., \& Baum, A. (2005). Environmental psychology. New York, NY: Routledge, Taylor and Francis Group.

Blum, M. L., \& Naylor, J. C. (2004). Industrial psychology: Its theoretical and social foundations. New Delhi: CBS Publishers \& Distributors.

Boyce, P. (2003). Human factors in lighting. New York, NY: Taylor and Francis Group.

Bridger, R. S. (2003). Introduction to ergonomics. New York, NY: Taylor and Francis Group.

Callender, J. H. (1997). Day Lighting. In J. H. Callender (Eds.), Time-saver standards for architectural design data (pp. 4/256-270). New York, NY: McGraw-Hill, Book Company.

Chao, L., Lijun, S., \& Xiangpei, H. (2012). A context-aware lighting control system for smart meeting rooms. Systems Engineering Procedia, 4, 314-323. http://dx.doi.org/10.1016/j.sepro.2011.11.081

Duru, D. D. (2001). Achieving effective woodwork practice in technical institutions in Nigeria. Studies in technical teacher education, 4(1), 23-28.

Elobiuke, H. U. (1998). Organization and administration of vocational education. Unpublished lecture manual. Enugu State University of Science and Technology. 
Enemali, J. D. (2006). Effective teaching and learning of technical vocational skills. Journal of vocational and technical education, 1(4), 9-28.

Evans, B. (2008). Lighting design. In G. Ramsey, \& H. R. Sleeper (Eds.), Ramsey/Sleeper architectural graphics standards (pp. 57-58). New York, NY: John Wiley \& Sons,

Etukudo, E. U. (2004). The effect of laboratory and discussion methods of teaching on students' performance in mathematics at the secondary level. The Nigerian teacher today, 12(1), 32-37.

Fielding, R. (2000). Lighting the learning environment. Journal of environmental psychology, 12, 305-317. Retrieved May 25, 2006, from http://www.desgnshare. com/research/lighting, lighting Envrl. htm

Georgewill, J. W. (1996). The effect of poor students' performance in physics external examination on science education. Journal of research in science and technology education, 1(2), 330-346.

Greene, B. F. (1997). Clerestory windows. In J. H. Callender (Ed.), Time-saver standards for architectural design data (pp. 4/267-270). New York, NY: McGraw-Hill Book Co.

Heerwagen, D. (2004). Passive and active environmental control-Informing the schematic designing of buildings. New York: McGraw-Hill Co. Inc.

Heschong, L .(2002). Day lighting and human performance. ASHRAE journal, 44(6), 65-67.

Jones, V. (2002). Ernst Neufert architects data. London: Blackwell Publishing.

Kalstrom, J. (1999, May 28). Green from the ground. Minneapolis/St Paul business journal. Retrieved May 25, 2006, from http://www.biz journals com/twin cities/stories/1999/05/31/focus $1 . h t m l$

Miller, Jr. G. T. (2005). Living in the environment: Principles, connections and solutions. Albany, N Y: Wadsworth Publishing Company.

Musa, A. R., Abdullah, N. A. G., Che-Ani, A. I., Tawil, N. M., \& Tahir, M. M. (2012). Indoor environmental quality for UKM architecture studio: An analysis on lighting performance. Procedia-Social and Behavioral Sciences, 60, 318-324. http:// dx.doi.org/10.1016/j.sbspro.2012.09.386

NCCE. (2008). Minimum standards for NCE teachers- vocational and technical. Abuja, Nigeria: National Commission for Colleges of Education.

Pattron, D. D. (2009). Classroom ergonomics implications for health, safety \& academic performance. Science and technology, General community. Retrieved http://from www.thefreelibrary.com

Prouse, R. (2003). Lighting Design. In G. Ramsey, \& H. R. Sleeper (Eds.), Ramsey/Sleeper architectural graphics standards (pp. 34-56). New York: John Wiley \& Sons.

Sanders, M. S., \& McCormick, E. J. (1993). Human factors in engineering and design. New York, NY: McGraw-Hill Inc.

Vandenberg, M. (1997). Light. In P. Tutt, \& D. Adler (Eds.), New metric handbook (pp. 412-433). London: Butterworth-Heinemann.

Winterbottom, M., \& Wilkins, A. (2009). Lighting and discomfort in the classroom. Journal of Environmental Psychology, 29(1), 63-75. http://dx.doi.org/10.1016/j.jenvp.2008.11.007

Wentz, C. A. (1999). Safety, health and environmental protection. New York, NY: McGraw-Hill Book Co.

Wodi, S. W. (2005). Effects of guided discovery instructional methods on auto-mechanics achievement and retention of technical school students. Unpublished Ph.D. Thesis. Department of Technology and Vocational Education, Enugu State University Science and Technology.

\section{Copyrights}

Copyright for this article is retained by the author(s), with first publication rights granted to the journal.

This is an open-access article distributed under the terms and conditions of the Creative Commons Attribution license (http://creativecommons.org/licenses/by/3.0/). 